\title{
Joanna Newerli-Guz
}

\author{
Akademia Morska w Gdyni \\ Wydział Przedsiebiorczości i Towaroznawstwa \\ e-mail: j.newerli-guz@wpit.am.gdynia.pl

\section{Innowacje na rynku przypraw i produktów przyprawowych}

\section{Kod JEL: O31}

Słowa kluczowe: innowacje, przyprawy, produkty przyprawowe

Streszczenie. Innowacje kosztują, ale są jedyną drogą umożliwiającą przedsiębiorstwu wprowadzenie na rynek nowego towaru lub usługi bądź odnalezienie się produktu na nowym rynku. W artykule przedstawiono definicje innowacji, ich podział i charakterystykę oraz przybliżono innowacje na rynku przypraw i produktów przyprawowych. Scharakteryzowano innowacje technologiczne związane bezpośrednio z procesem produkcji, innowacje produktowe związane $\mathrm{z}$ produktem oraz marketingowe związane ze zmianą strategii marketingowych.

\section{Wprowadzenie}

Przyprawy są to „naturalne produkty roślinne lub ich mieszanki używane do poprawienia smaku, aromatyzowania potraw oraz $\mathrm{w}$ niektórych przypadkach poprawy walorów wizualnych" (PN-EN ISO 76:2009). Mieszanki przyprawowe zaś to produkty otrzymane przez wymieszanie wysuszonych, rozdrobnionych lub całych surowców takich jak: kora, korzenie, kłącza, ziela, liście, kwiaty, pąki, owoce i nasiona przeznaczone do poprawienia zapachu i wyglądu produktów spożywczych (PN-A-86967). Coraz częściej składnikami mieszanek przyprawowych są substancje inne niż przyprawy, zioła i warzywa przyprawowe. Wiele jest też produktów w postaci sypkiej, past, sosów, które pełnią funkcje przypraw, a do przypraw nie powinny być zaliczane. Różnorodność tych produktów na 
rynku może zadziwiać i często stawia konsumenta przed dylematem związanym z wyborem właściwego produktu, w pełni spełniającego jego wymagania.

Aaker i Myers (1987, za: Kaczmarczyk, 2013) wyróżnia trzy kategorie cech kojarzonych przez nabywców z produktami:

- cechy fizyczne, które mogą być mierzone przy pomocy skal ilościowych (przedziałowych i stosunkowych), np. waga, temperatura, odległość, kolor, słodkość, wartość,

- cechy pseudofizyczne, które w większości mogą być mierzone przy pomocy skal jakościowych (nominalnych i porządkowych), np. smak, aromat, ostrość,

- korzyści, które mogą być mierzone w większości przy pomocy skal jakościowych, np. wygoda, bezpieczeństwo, możliwość mieszania z innymi składnikami, energooszczędność.

We wszystkich tych grupach można znaleźć cechy, na które szczególną uwagę zwracają konsumenci przypraw i produktów przyprawowych oraz ich producenci. Wybrane z nich kształtują innowacyjny charakter tych produktów i są bardziej niż inne podatne na przekaz marketingowy. Konsumentów interesuje smak, aromat, łatwość i szybkość przygotowania potraw z wykorzystaniem przypraw i produktów przyprawowych, rzadziej zaś racjonalność spożycia, zawartość substancji dodatkowych czy wykorzystane procesy technologiczne (NewerliGuz, 2014)

Celem pracy była identyfikacja innowacji technologicznych i nietechnologicznych na rynku przypraw i produktów przyprawowych. Wykorzystane w pracy metody badawcze opierały się na analizie literatury przedmiotu oraz własnych obserwacjach.

\section{Innowacje - definicja, podział}

Innowacja jest nierozerwalnie związana z wykorzystaniem okazji do stworzenia nowego dobra, usługi, procesu (Madhaven, Koka, Prescot, 1998). Dla rozwoju rynku i istniejących na nim oraz przyszłych przedsiębiorstw istotne są nowości, w tym różnego rodzaju innowacje. Wyróżnia się 7 grup produktów ze względu na ich nowość:

- produkty kreatywne,

- produkty innowacyjne,

- nowe opakowania istniejących produktów,

- zmiana składu istniejących produktów,

- nowe postacie istniejących produktów,

- przeniesienie ulepszeń do istniejących produktów,

- rozszerzenie istniejących linii produktów (Winger, Wall, 2006).

M.O. Ilori, J.S. Oke, S.A. Sanni (2000) do czynników istotnych w kreowaniu sukcesu nowych produktów na rynku zaliczają: 
- marketing i współpracę kierowniczą,

- siłę komunikacji marketingowej i związane z nią nakłady,

- potrzeby rynku, jego wielkość i możliwości rozwoju.

Istotny, szczególnie w przypadku produktów spożywczych, jest również unikalny, luksusowy charakter produktu, zrozumienie potrzeb konsumentów, ich postaw, preferencji, a w tym walory sensoryczne żywności oraz sposób jej produkcji.

Według Podręcznika Oslo Manual (międzynarodowego podręcznika metodologicznego badań statystycznych innowacji zalecanego w krajach OECD i UE) (Oslo Manual, 2005) innowacja jest to wdrożenie nowego lub istotnie ulepszonego produktu (wyrobu lub usługi), nowego lub istotnie ulepszonego procesu, nowej metody marketingu lub nowej metody organizacji w zakresie praktyk biznesowych, organizacji miejsca pracy bądź relacji ze środowiskiem zewnętrznym. Na potrzeby polityki naukowo-technicznej, a także dla zachowania porównywalności w czasie z wynikami dotychczasowych badań statystycznych innowacji w wielu przypadkach użyteczne jest również stosowanie węższej definicji innowacji. Definicja ta pochodząca z drugiego wydania Oslo Manual uznaje za innowacje jedynie tzw. innowacje techniczne, tzn. nowe lub istotnie ulepszone produkty i procesy (TPP innovations-technological product and process innovations).

Produkty (wyroby i usługi), procesy i metody (techniczne, organizacyjne i marketingowe) są innowacjami, jeśli są nowe lub istotnie ulepszone przynajmniej z punktu widzenia wdrażającego je przedsiębiorstwa. Oznacza to, że definicja innowacji, według podręcznika Oslo Manual, obejmuje pełne spektrum nowości - od nowości na skalę światową (tzw. innowacje absolutne - new to the world), przez nowości w skali rynku, na którym działa przedsiębiorstwo (new to the market), po nowości tylko z punktu widzenia danego przedsiębiorstwa (new to the firm). Innowacje można podzielić na cztery rodzaje:

1. Innowacja produktowa - są to zmiany polegające na wprowadzeniu nowego produktu (towaru, usługi) lub udoskonalenia już istniejącego w stosunku do jego właściwości lub planowanych zastosowań. Obejmuje ona znaczną poprawę w specyfikacjach technicznych, komponentach, materiałach, oprogramowaniach, łatwości obsługi lub innych cechach funkcjonalnych. Projekt jest integralną częścią rozwoju i wdrażania innowacji produktowych. Jednak zmiany w projekcie, które nie pociągają za sobą istotnych zmian cech funkcjonalnych produktu lub planowanych jego zastosowań, nie są uznawane za innowacje produktowe.

2. Innowacja procesowa - jest to wdrożenie nowej lub znacząco udoskonalonej metody produkcji lub dostawy. Dotyczy to również znaczących zmian w obrębie technik, sprzętu i/lub oprogramowania. Innowacje technologiczne mogą być przeznaczone w celu zmniejszenia kosztów jednostkowych produkcji lub dostawy, podwyższenia jakości lub produkcji albo dostarczenia 
nowych lub znacząco ulepszonych produktów. Innowacja procesowa inaczej nazywana jest techniczną, technologiczną lub konstrukcyjną.

3. Innowacja marketingowa - to wdrożenie nowej metody marketingowej obejmującej znaczące zmiany w: konstrukcji produktu lub opakowania, lokowaniu produktu, promocji produktów i cen. Innowacje marketingowe mają na celu lepsze odpowiadanie na potrzeby klientów, otwarcie nowych rynków lub nowe pozycjonowanie produktu firmy na rynku, w celu zwiększenia sprzedaży firmy.

4. Innowacja organizacyjna - to wdrożenie nowej metody organizacyjnej w praktykach biznesowych firmy, organizacji miejsca pracy lub w stosunkach zewnętrznych (Oslo Manual, 2005)

Innowacje dzieli się też na przełomowe - wnoszące nowe wartości, kreujące nowe rynki i, zdecydowanie częstsze, innowacje inkrementalne (podtrzymujące, przyrostowe, ewolucyjne, często naśladowcze). Weber (1996, s. 470-471) w zależności od przyczyn powstania innowacji dzieli je na rutynowe, wymuszone i wynikające z okazji. Wielu badaczy rozpoczynając od Schumpetera (1939, s. 85), odróżnia innowację od inwencji. Inwencja to akt kreatywności intelektualnej, nieistotny dla analizy ekonomicznej, zaś innowacja to decyzja ekonomiczna polegająca na wdrożeniu inwencji.

Innowacje na rynku przypraw i produktów przyprawowych mają również na celu poprawę rachunku ekonomicznego wdrażających je firm. Innowacje w przemyśle spożywczym bardzo długo związane były wyłącznie z innowacjami $\mathrm{w}$ procesie technologicznym. Miały one na celu usprawnienie procesu technologicznego, obniżenie jego kosztochłonności i wzrost wydajności. Wydaje się jednak, że wykorzystanie tych innowacji jest niewielkie, jeżeli chodzi o wpływ na zachowanie konsumenta na rynku, wybór i zakup konkretnego produktu. Wyjątkiem są innowacje wpływające bezpośrednio na jakość produktu, którą konsument może docenić. Obecnie coraz częstsze są jednak innowacje nietechnologiczne.

\section{Innowacje technologiczne na rynku przypraw i produktów przyprawowych}

Innowacje technologiczne dotyczące przypraw mają stosunkowo ograniczony zasięg ze względu na niezbyt skomplikowany sposób produkcji (rys. 1).

$\mathrm{Na}$ etapie uprawy surowca innowacyjne jest wprowadzenie nowych odmian i gatunków roślin przyprawowych o ustalonej tożsamości botanicznej oraz wysokiej zawartości składników czynnych, determinujących ich wysoką jakość przyprawową. Innowacyjne i często pokazywane w przekazie marketingowym okazało się też unikanie środków chemicznych, nawozów sztucznych i środków ochrony roślin nazywane ,uprawą naturalną” bądź też ekologiczną (tylko wtedy, gdy poddano ją certyfikacji). 


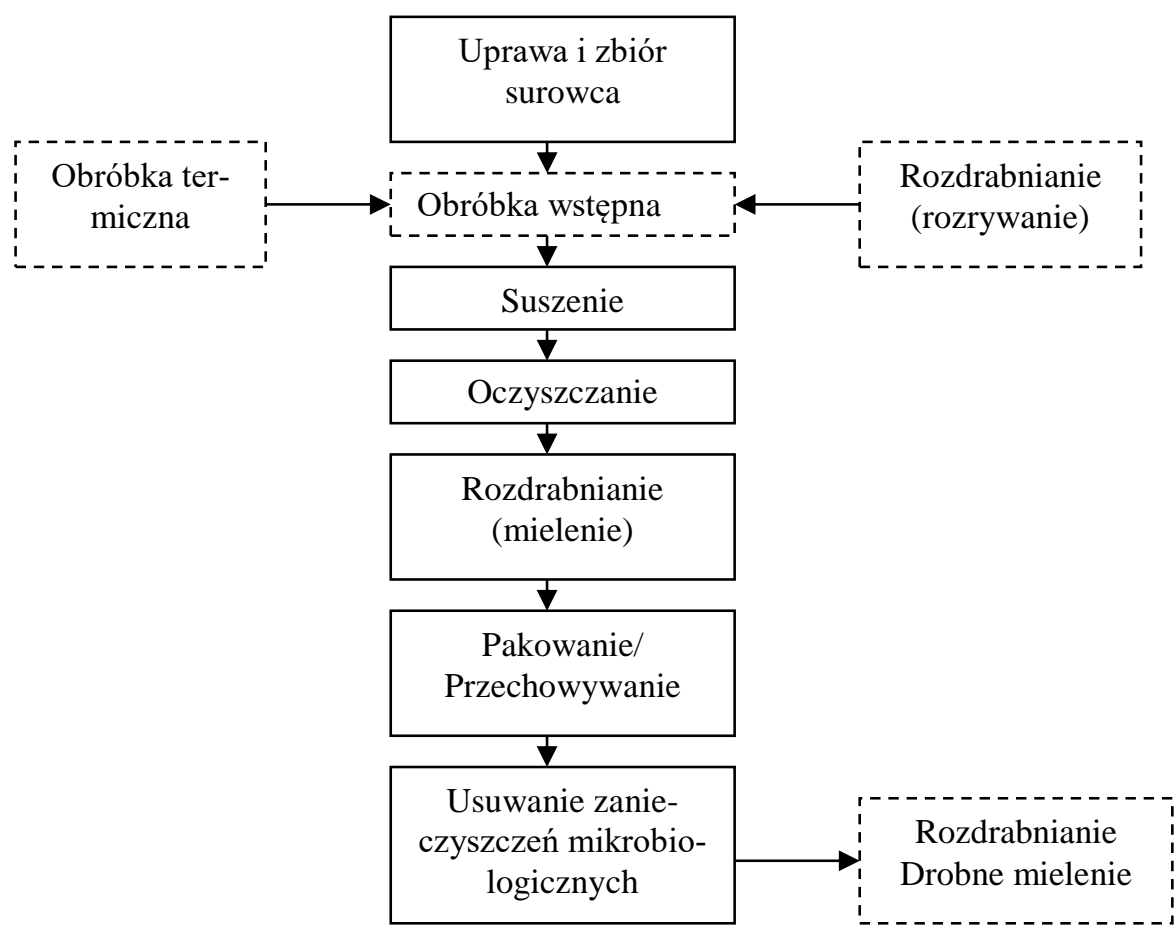

Rysunek 1. Produkcja ziół i przypraw

Źródło: opracowanie na podstawie Schweiggert, Carle, Schieber (2007).

Po zbiorze surowca w przypadku ziół i przypraw stosuje się stabilizację mającą na celu zahamowanie zmian zachodzących w jego jakości. Najczęściej stabilizacja jest procesem suszenia, który w miarę możliwości powinien być najkrótszy, bowiem długie więdnięcie roślin powoduje straty w substancjach czynnych (Elbanowska, 1994). Senderski (2004) również zwraca uwagę na warunki suszenia i sposób przechowywania surowca.

Bardzo istotnym procesem $\mathrm{w}$ produkcji przypraw jest suszenie związane z odpowiednim ich oczyszczeniem - usunięciem zanieczyszczeń mikrobiologicznych. Proces ten nie może przebiegać w zbyt wysokiej temperaturze ze względu na straty związków lotnych zawartych w przyprawach. Suszenie naturalne, zwane też powietrznym, jest często wykorzystywane w uprawach ekologicznych, lecz najczęściej wykorzystuje się suszenie termiczne bazujące na termicznym źródle czynnika suszącego. Do innowacyjnych, rzadziej wykorzystywanych metod należą: liofilizacja - suszenie sublimacyjne oraz napromieniowywanie produktu promieniowaniem jonizującym; przy czym pierwszy proces uważany jest za nowoczesny, niebudzący kontrowersji. Drugi zaś mimo wysokiej wydajności, 
zachowania wartości przyprawowych i skutecznej sterylizacji budzi wiele zastrzeżeń, w tym natury etycznej (Dhanya, Mishra, Khaleei, 2011). Innowacyjną alternatywą dla klasycznego suszenia jest też wykorzystanie reaktora plazmy nietermicznej do sterylizacji produktów organicznych, w tym przypraw. Aparat do sterylizacji plazmowej, w którym temperatura nie przewyższa $40^{\circ} \mathrm{C}$, jest mniej kosztochłonny niż urządzenia przemysłowe generujące promieniowanie jonizujące i autoklawy przemysłowe (Grabowski, 2014).

W przypadku mieszanek przyprawowych proces technologiczny wzbogacony jest o odpowiednie zestawienie składników i wymieszanie ich w odpowiednich proporcjach. Składniki te w mieszankach typu blends są samymi przyprawami i ziołami, a w mieszankach seasoning również innymi składnikami, które wzbudzają wiele kontrowersji, tj. sól kuchenna - chlorek sodu, cukier, substancje dodatkowe, tj. glutaminian sodu (MSG), guanylan wapnia, kwas inozynowy, inozynian disodowy, inozynian dipotasowy, rybonukleotyd wapnia, kwas cytrynowy, hydrolizaty drożdżowe, słodziki, aromaty, barwniki.

Istotny jest tutaj odpowiedni stopień rozdrobnienia oraz właściwe opakowanie. Opakowanie produktów nie stanowi jednak innowacji technologicznych, które mogą być w obrębie produktu lub są związane z procesem produkcyjnym, dlatego też innowacje opakowań omówiono w dalszej części.

\section{Innowacje nietechnologiczne na rynku przypraw i produktów przyprawowych}

Innowacje nietechnologiczne (marketingowe) na rynku przypraw związane są ze zmianą strategii marketingowych przedsiębiorstw konfekcjonujących i produkujących przyprawy. Według autorki rozwinęly się one w dwóch kierunkach:

1. Związanym $z$ wprowadzeniem nowego produktu na rynek:

- nowa mieszanka, o zmienionym składzie, wykorzystująca nieznane dotąd lub rzadko spotykane składniki, niebędące charakterystycznymi dla danego regionu,

- nowe opakowanie, nowoczesne zamknięcie tego opakowania, jego oznakowanie,

- nowe, nieoczywiste przeznaczenie.

2. Związanym $\mathrm{z}$ wprowadzeniem produktu na nowy rynek:

- marki własne sieci handlowych,

- produkty sprzedawane w sklepach chemiczno-drogeryjnych i drogeriach sieciowych,

- przyprawy w postaci płynnej, pasty przeznaczone do konkretnego produktu spożywczego,

- rynek suplementów diety i produktów specjalnego przeznaczenia żywieniowego.

Innowacyjne jest pojawienie się marek tańszych tego samego producenta czy też marek własnych sieci handlowych. Kolejnym przejawem tego rodzaju 
innowacji jest kreowanie nowych potrzeb na rynku tego rodzaju produktów. Faktem stała się dominacja mieszanek przyprawowych typu seasoning, które należy jasno odróżnić od mieszanek typu blends, które składają się tylko z ziół i przypraw. Na rynku pojawiają się ponadto coraz nowsze wariacje mieszanek do bardzo szerokiego wachlarza potraw, produkty o zmienionym składzie - bez dodatku soli, cukru, tylko z naturalnych składników, ekologiczne (certyfikowane) przeznaczone dla konkretnych grup konsumentów (wegetarian, wegan).

Innowacyjne stały się też metody promocji, w tym reklamy przypraw i produktów przyprawowych, z wykorzystaniem product placement, czyli pokazywania ich jako rekwizytów w filmach i w szczególności w programach o tematyce kulinarnej z udziałem znanych kucharzy, restauratorów i celebrytów.

P. Cyrek i M. Cyrek (2007) wskazują ponadto na szczególnie nowatorskie rozwiązania w branży opakowalniczej, gdzie opakowania nie pełnią już funkcji wyłącznie zabezpieczających, transportowych i informacyjnych. Ich funkcje dopasowują się do konkretnego produktu, zmian w otoczeniu i oczekiwań klientów. Opakowania przypraw i produktów przyprawowych ewoluują od najpowszechniej wykorzystywanych torebek z laminatów z folią aluminiową do słoiczków, młynków z gotowymi mieszankami, opakowań strunowych czy opakowań pozwalających na samodzielne zmieszanie kilku składników.

\section{Podsumowanie}

Według D. Padberga i R.E. Westgrena (1979), konsumenci dokonując zakupów produktów żywnościowych, wykazują z jednej strony specyficzną niechęć do produktów zupełnie nowych, oczekując z drugiej strony nowych produktów, które jednak mają być podobne do tych, które już znają. W tym kontekście ograniczony jest rozwój innowacji, gdyż wiele z nich nie wzbudziłoby zainteresowania konsumentów. Wykorzystanie napromieniowywania i podejście konsumentów do tego rodzaju utrwalania przypraw jest tego potwierdzeniem.

Innowacje obecne na rynku przypraw i produktów przyprawowych można uznać zarówno za korzystne, jak i niekorzystne dla konsumenta. Do innowacji korzystnych zalicza się wykreowanie bogatej i zróżnicowanej oferty handlowej, wzrost popularności przypraw, w szczególności tych nieznanych i niewykorzystywanych w tradycyjnej kuchni polskiej, powstawanie ciekawych połączeń smakowo-zapachowych $\mathrm{w}$ postaci mieszanek przyprawowych i innych produktów przyprawowych, nowe ich postaci i nowe opakowania. Innowacje niekorzystne są natomiast najczęściej związane z zastrzeżeniami natury zdrowotnej: nieobecnością lub niską zawartością przypraw w przyprawach, wysoką zawartością soli i glutaminianu sodu.

Jak wynika z badań G. Bortnowskiej (Bortnowska, Kałużna-Zajączkowska, 2011), 4,1\% z przebadanych 219 mieszanek przyprawowych w ogóle nie zawie- 
rało przypraw roślinnych, najczęściej deklarowanymi składnikami poza przyprawami były glutaminian sodu $68 \%$, sól kuchenna $67,6 \%$ i aromaty spożywcze $48,9 \%$. Zawartość chlorku sodu w mieszankach uniwersalnych typu Vegeta wynosi nawet do 64,59\% przy obecności warzyw do 15\% (Śmiechowska, Kaczmarczyk, 2014). Proponowana przez producentów zamiana glutaminianu sodu na hydrolizaty białkowe i ekstrakty drożdżowe jest również niekorzystna ze względu na zawarty w nich glutaminian sodu i sól kuchenną (w ilości nawet do kilkudziesięciu procent). Wysokie spożycie mieszanek zawierających tego rodzaju składniki ma bardzo negatywy wpływ na zdrowie konsumentów związane ze zbyt wysoką podażą soli kuchennej w diecie. Poza tym powstaje pytanie, czy rzeczywiście wszystkie z tych produktów należy zaliczać do przypraw, czy nie są to połączenia w niektórych wypadkach samych substancji dodatkowych.

Dla producentów innowacje stały się już niezbędnym składnikiem biznesplanu, bez nich nie ma obecnie już mowy o zaistnieniu i przetrwaniu na rynku, mają one głownie na celu poprawę rachunku ekonomicznego prowadzonej działalności.

\section{Bibliografia}

Bortnowska, G., Kałużna-Zajączkowska, J. (2011). Preferencje wyboru przypraw sypkich do potraw przez osoby pracujące zawodowo $\mathrm{z}$ uwzględnieniem innowacyjnych zmian $\mathrm{w}$ ich produkcji. Roczniki Państwowego Zakładu Higieny, 62 (4), 445-452.

Cyrek, P., Cyrek, M. (2007). Innowacyjność determinantą konkurencyjności przedsiębiorstw przemysłu spożywczego. W: S. Makarski. P. Cyrek, S. Dybka, A. Kasprzyk (red.), Transfer wiedzy i działań innowacyjnych w obszarze agrobiznesu (s. 7-14). Rzeszów: Wyd. Uniwersytetu Rzeszowskiego.

Dhanya, R., Mishra, B.B., Khaleei, K.M. (2011). Effect of gamma irradiation on corcuminoids and volatile oils of fresh turmeric (Curcuma longa). Radiation Physics and Chemistry, 80 (11), $1247-1249$.

Elbanowska, A. (1994). Suszenie i przechowywanie surowców zielarskich. Poznań: Instytut Roślin i Przetworów Zielarskich.

Grabowski, M. (2014). Czy istnieje możliwość zastosowania niskociśnieniowej zimnej plazmy do sterylizacji przypraw? W: Wplyw innowacji na rozwój towaroznawstwa w XXI wieku (s. 5760). Gdynia: Naukowe Koło Towaroznawstwa, Akademia Morska.

Ilori, M.O., Oke, J.S., Sanni, S.A. (2000). Management of new product development in selected food companies in Nigeria. Technovation, 20 (6), 333-342.

Kaczmarczyk, S.(2013). Zastosowanie badań marketingowych do pozycjonowania produktów. Zeszyty Naukowe Uniwersytetu Szczecińskiego, 777, Problemy Zarzadzania, Finansów i Marketingu, 32, 79-93.

Madhaven, R., Koka, B.R., Prescot, J.E. (1998). Networks in transition: How industry events (re) shape inter firm relationships. Strategic Management Journal, 19 (5), 439-459.

Newerli-Guz, J. (2014). Racjonalność spożycia a wybór mieszanek przyprawowych przez konsumentów. Roczniki Naukowe Stowarzyszenia Ekonomistów Rolnictwa i Agrobiznesu, 16 (4), $208-212$. 
Oslo Manual: Guidelines for Collecting and Interpreting Innovation Data. 3rd Edition, The Measurement of Scientific and Technological Activities (2005). Paris: OECD Publishing. DOI: http://dx.doi.org/10.1787/9789264013100-en.

Padberg, D., Westgren, R.E. (1979). Product competition and consumer behavior in the food industries. American Journal of Agricultural Economics, 61 (4), 620-625.

PN-A-86967 Przyprawy ziołowe - Mieszanki przyprawowe.

PN-EN ISO 76:2009. Przyprawy ziołowe - Nazewnictwo botaniczne.

Senderski, M. (2004). Prawie wszystko o ziołach. Poradnik. Podkowa Leśna: Wydawnictwo Mateusz E. Senderski.

Schumpeter, J.(1939). Business cycles: a theoretical, historical, and statistical analysis of the capitalists process. New York: McGraw-Hill.

Schweiggert, U., Carle, R., Schieber, A. (2007). Conventional and alternative processes for spice production - a review. Trends in Food Science \& Technology, 18 (5) 260-268.

Śmiechowska, M., Kaczmarczyk, A. (2014). Mieszanki przyprawowe - ukryte źródło soli. Problemy Higieny i Epidemiologii, 95 (1), 128-130.

Weber, R.A. (1996). Zasady zarządzania organizacjami. Warszawa, PWE.

Winger, R., Wall, G. (2006). Food product innovation. Rome: Food and Agriculture Organization of United Nations.

\section{Innovation on Spices and Spice Products Market}

Keywords: innovations, spices, spice products,

Summary. Innovations cost money but they are the only way to enable the company to launch a new product or service on the market, or find a products/services place on the new market. The article presents the definitions of innovation, their division and characteristics. The article also presents innovations on the spices and spice products market: technological innovation directly associated with the production process, product innovations related to the product and the marketing innovations associated with the change of marketing strategy.

Translated by Joanna Newerli-Guz

\section{Cytowanie}

Newerli-Guz, J. (2016). Innowacje na rynku przypraw i produktów przyprawowych. Marketing i Zarządzanie, 3 (44), 361-369. 